\title{
Effect of Aliphatic Polyamines on Growth and Macromolecular Syntheses in Bacteria
}

\author{
By U. BACHRACH AND A. WEINSTEIN \\ Department of Bacteriology, Institute of Microbiology, The Hebrew University- \\ Hadassah Medical School, Jerusalem, Israel
}

(Accepted for publication 17 October 1969)

SUMMARY

The effect of synthetic and naturally occurring polyamines on bacterial growth was studied. The tetra-amine spermine was the most potent antibacterial agent and showed maximal activity at high $\mathrm{pH}$ values. The antibacterial action of the triamines was dependent upon the number of the primary amino groups in the polyamine molecule and was maximal when it contained a $-\mathrm{N}\left(\mathrm{CH}_{2}\right)_{7} \mathrm{~N}$ - moiety. Polyamines, in low concentrations, stimulated the incorporation of $\left[{ }^{14} \mathrm{C}\right]$ uracil into the nucleic acids of growing bacteria, whereas higher concentrations were inhibitory. In contrast the incorporation of $\left[{ }^{14} \mathrm{C}\right]$ valine into bacterial proteins was inhibited by polyamines, even in low concentrations.

\section{INTRODUCTION}

The naturally occurring polyamines, spermine, $\mathrm{NH}_{2}\left(\mathrm{CH}_{2}\right)_{3} \mathrm{NH}\left(\mathrm{CH}_{2}\right)_{4} \mathrm{NH}\left(\mathrm{CH}_{2}\right)_{3} \mathrm{NH}_{2}$ and spermidine, $\mathrm{NH}_{2}\left(\mathrm{CH}_{2}\right)_{3} \mathrm{NH}\left(\mathrm{CH}_{2}\right)_{4} \mathrm{NH}_{2}$, inhibit the growth of various microorganisms, mainly Gram-positive bacteria (Rozansky, Gurevitch, Brzezinsky \& Eckerling, 1949; Rozansky, Bachrach \& Grossowicz, 1954; Grossowicz, Razin \& Rozansky, 1955). Previous work has shown that the antimicrobial action is maximal at alkaline $\mathrm{pH}$ values (Rozansky et al. 1954) and that polyamines inhibit protein synthesis in growing bacteria (Razin \& Rozansky, 1959; Friedman \& Bachrach, 1966; Mills \& Dubin, 1966; Ezekiel \& Brockman, 1968), in bacterial extracts (Hershko, Amoz \& Mager, 196I; Mager, Benedict \& Artman, 1962; Martin \& Ames, 1962) and in mammalian cells (Goldstein, I965; Ochoa \& Weinstein, 1965). On the other hand, RNA synthesis is stimulated by polyamines in low concentrations, while high concentrations exert an inhibitory effect (Doerfler, Zillig, Fuchs \& Albers, 1962; Krakow, I963; Fox, Robinson, Haselkorn \& Weiss, I964; Fox \& Weiss, 1964; Dykstra \& Herbst, I965; Goldstein, I965; Mills \& Dubin, I966; O’Brien, Olenick \& Hahn, 1966; Caldarera, Moruzzi, Barbiroli \& Moruzzi, I968; Moruzzi, Barbiroli \& Caldarera, 1968; Petersen, Kröger \& Hagen, 1968). Synthetic polyamines, resembling spermidine in their structure, behave like naturally occurring polyamines in that they stabilize RNA against thermal denaturation (Goldstein, 1966) and serve as growth factors for some lactobacilli (Guirard \& Snell, 1964).

The object of the present work was to test the effects of synthetic polyamines on growth and macromolecular syntheses in bacteria. It will be shown that these synthetic compounds resemble naturally-occurring polyamines in their bactericidal activity. This activity is dependent upon the number of free amino groups and on the length of the polyamine molecule. 


\section{METHODS}

Chemicals. Spermine tetrahydrochloride and spermidine trihydrochloride were supplied by Fluke AG, Buchs, Switzerland. 3,3'-Diaminodipropyl amine was obtained from Eastman, Kodak, Rochester, N.Y., U.S.A. The other synthetic polyamines were kindly provided by Dr E. F. Elsager (Parke, Davis \& Co., Ann Arbor, U.S.A.). DL- $\left[\mathrm{I}-{ }^{14} \mathrm{C}\right]$ Valine $\left(0.35 \mathrm{mg} . / 0 \cdot \mathrm{I} \mathrm{mCi} ; 33.9 \mu \mathrm{Ci} / \mathrm{ml}\right.$.) and $\left[2-{ }^{14} \mathrm{C}\right]$ uracil $(0.276 \mathrm{mg} . / 0 \cdot \mathrm{I} \mathrm{mCi}$; $25 \mu \mathrm{Ci} / \mathrm{ml}$.) were purchased from the Radiochemical Centre, Amersham, Buckinghamshire, England.

Bacteria and media. Escherichia coli strain B and Staphylococcus aureus were grown in nutrient broth (Difco Laboratories, Detroit, Mich., U.S.A.). Antibacterial activity was determined by twofold dilutions in nutrient broth. To each dilution of the antibacterial agent $(\mathrm{I} \mathrm{ml}$.) was added $0.05 \mathrm{ml}$. of a diluted bacterial suspension containing $5 \times 10^{5}$ organisms $/ \mathrm{ml}$. Results were recorded after incubation at $37^{\circ}$ for $20 \mathrm{hr}$.

$R N A$ and protein synthesis. The incorporation of $\left[2-{ }^{14} \mathrm{C}\right]$ uracil into bacterial nucleic acids was determined by growing Escherichia coli in $20 \mathrm{ml}$. quantities of nutrient broth to $5 \times 10^{8}$ organisms $/ \mathrm{ml}$., whereupon radioactive uracil $(\mathrm{I} \cdot 2 \mu \mathrm{Ci})$ and the required polyamine were added. At intervals, $2 \mathrm{ml}$. portions were withdrawn and added to $2 \mathrm{ml} .10 \%(\mathrm{w} / \mathrm{v})$ trichloroacetic acid containing $0.0 \mathrm{I} \%(\mathrm{w} / \mathrm{v})$ uracil. After standing in the cold for at least $30 \mathrm{~min}$., samples were filtered through membrane filters $(0.45 \mu$, Millipore Filter Corp., Bedford, Mass., U.S.A.) which were then washed with $25 \mathrm{ml}$. trichloroacetic acid, dried, mounted on planchets and counted by a Nuclear Chicago thin window gas flow counter.

The incorporation of radioactive valine into bacterial proteins was similarly determined. Radioactive valine $(6 \cdot 8 \mu \mathrm{Ci})$ and the respective polyamine were added to $20 \mathrm{ml}$. portions of the bacterial cultures. Two $\mathrm{ml}$. portions were withdrawn at various times and added to $2 \mathrm{ml}$. $10 \%(\mathrm{w} / \mathrm{v})$ trichloroacetic acid containing I $\%(\mathrm{w} / \mathrm{v})$ casamino acids (Difco Laboratories Detroit, Mich., U.S.A.). Filters were washed, dried and counted as above.

Table I. Effect of polyamines on growth of Staphylococcus aureus and Escherichia coli

\begin{tabular}{|c|c|c|c|c|}
\hline \multicolumn{3}{|c|}{ Compound } & \multirow{2}{*}{\multicolumn{2}{|c|}{$\begin{array}{cc}\text { Staphylococcus } & \text { Escherichia } \\
\text { aureus coli } & \text { colitory } \\
\text { Minimal inhibitory } & \\
\text { concentration }(\mu \mathrm{g} . / \mathrm{ml} .)\end{array}$}} \\
\hline No & Formula & $\begin{array}{c}\text { Name or } \\
\text { abbreviation }\end{array}$ & & \\
\hline I & $\mathrm{a}-\mathrm{NH}\left(\mathrm{CH}_{2}\right)_{4} \mathrm{NH}-\mathrm{a}^{*}$ & Spermine & 2 & 17 \\
\hline 2 & $\mathrm{a}-\mathrm{NH}\left(\mathrm{CH}_{2}\right)_{2} \mathrm{NH}_{2}$ & $\mathrm{C}_{2}$ & 45 & 365 \\
\hline 3 & $\mathrm{a}-\mathrm{NH}\left(\mathrm{CH}_{2}\right)_{2} \mathrm{OH}$ & $\mathrm{C}_{2}-\mathrm{OH}$ & 100 & 1400 \\
\hline 4 & $\mathrm{a}-\mathrm{NH}-\mathrm{a}$ & $\mathrm{C}_{3} \dagger$ & 6 & 400 \\
\hline 5 & $\mathrm{a}-\mathrm{N}\left(\mathrm{CH}_{3}\right)-\mathrm{a}$ & $\mathrm{C}_{3}-\mathrm{NCH}_{3}$ & 14 & 450 \\
\hline 6 & $\mathrm{a}-\mathrm{NH}\left(\mathrm{CH}_{2}\right)_{4} \mathrm{NH}_{2}$ & Spermidine & 12 & 390 \\
\hline 7 & $\mathrm{a}-\mathrm{NH}\left(\mathrm{CH}_{2}\right)_{5} \mathrm{NH}_{2}$ & $\mathrm{C}_{5}$ & 3 & 460 \\
\hline 8 & $\mathrm{a}-\mathrm{NH}\left(\mathrm{CH}_{2}\right)_{6} \mathrm{NH}_{2}$ & $\mathrm{C}_{6}$ & 4 & 270 \\
\hline 9 & a-NH $\left(\mathrm{CH}_{2}\right)_{7} \mathrm{NH}_{2}$ & $\mathrm{C}_{7}$ & 4 & 140 \\
\hline
\end{tabular}




\section{RESULTS \\ Effect on bacterial growth}

Spermine and spermidine, the naturally-occurring polyamines, are known to be antibacterial. To find whether this inhibitory action is common to a variety of polyamines, various synthetic polyamines were used. Synthetic polyamines were also used to determine the optimal structure for an antimicrobial polyamine. Staphylococcus aureus was more sensitive than Escherichia coli to the inhibitory action of the polyamines; the tetra-amine spermine was the most potent antibacterial agent tested (Table I). It is also evident from Table I that the two primary amino groups were essential for the antibacterial action; the substitution of an amino group by a hydroxy radical, decreased the antibacterial activity significantly (compound no. 3). The methylation of the secondary amino group of a triamine resulted in a slight decrease of activity (see compound no. 4, 5). Results shown in Table I lead us to suggest that maximal antibacterial activity is obtained when the triamine contains a $-\mathrm{N}\left(\mathrm{CH}_{2}\right)_{7} \mathrm{~N}-$ moiety. As expected, the antibacterial activity of the polyamines was dependent on the $\mathrm{pH}$ value of the medium and was maximal at alkaline $\mathrm{pH}$ values (Fig. I).

\section{Effect on macromolecular synthesis}

The effect of polyamines on macromolecular synthesis was studied. Spermine, in low concentrations, stimulated the incorporation of $\left[2-{ }^{14} \mathrm{C}\right]$ uracil into trichloracetic acid-insoluble material in growing Escherichia coli. Maximal stimulation was obtained with $100 \mu \mathrm{g}$. spermine/ml. Ribonucleic acid synthesis was inhibited by higher concentrations of spermine (Fig. 2). It is noteworthy that RNA synthesis was stimulated by spermine in concentrations which inhibited growth. Similar results were obtained with the synthetic polyamine no. $\mathrm{C} 7, \mathrm{NH}_{2}\left(\mathrm{CH}_{2}\right)_{3} \mathrm{NH}\left(\mathrm{CH}_{2}\right)_{7} \mathrm{NH}_{2}$; again, RNA synthesis was stimulated by the polyamine in low concentrations inhibited by larger concentrations (Fig. 3).

When polyamines were added to growing cultures of Escherichia coli an inhibition of protein synthesis was noticed, even in the presence of low concentrations of polyamine. Spermine at 100 and $25 \mu \mathrm{g}$. $/ \mathrm{ml}$. inhibited the incorporation of $\left[\mathrm{I}^{14} \mathrm{C}\right]$ valine by 50 and $15 \%$, respectively (Fig. 4). Similar concentrations of spermine stimulated the incorporation of radioactive uracil into bacterial RNA (see Fig. 2). The synthetic triamine no. $\mathrm{C}_{7}$, exerted a similar inhibitory effect on protein synthesis in growing E. coli. Inhibitions of 100 and $75 \%$, respectively, were produced by the polyamine in concentrations of 17 and $9 \mathrm{mg} . / \mathrm{ml}$. of medium (Fig. 5).

\section{DISCUSSION}

The results described in this paper clearly show that Staphylococcus aureus, a Grampositive bacterium was more sensitive to the antibacterial action of polyamines than the Gram-negative Escherichia coli. This is in agreement with the results reported elsewhere for spermine and spermidine (Rozansky et al. 1954). Although the tetraamine spermine was most effective in inhibiting the growth of $S$. aureus and E. coli, significant inhibitions of growth also resulted from addition of triamines. It appears that the number of the primary amino groups and the length of the aliphatic chains play a role in inhibiting bacterial growth. Thus, when one primary amino group of the 
triamine was substituted by a hydroxyl group, a significant decrease of antibacterial activity was observed. However, the presence of a secondary amino group in the triamine molecule is not essential for growth inhibition. This is demonstrated by the fact that methylation of the secondary amine caused only a slight change in antimicrobial activity. An aliphatic chain with seven carbon atoms seemed to be optimal for the inhibition of the growth of $E$. coli. It is of interest that cadaverine $\left(\mathrm{NH}_{2}\left(\mathrm{CH}_{2}\right)_{5} \mathrm{NH}_{2}\right)$ was most effective in protecting protoplast-infecting agent against thermal inactivation (Fraser \& Mahler, 1958). This has been attributed to the $\mathrm{N}$ to $\mathrm{N}$ distances $(7 \cdot 3 \AA)$ in the cadaverine molecule which is similar to the distances between the phosphate oxygens in the DNA molecule.

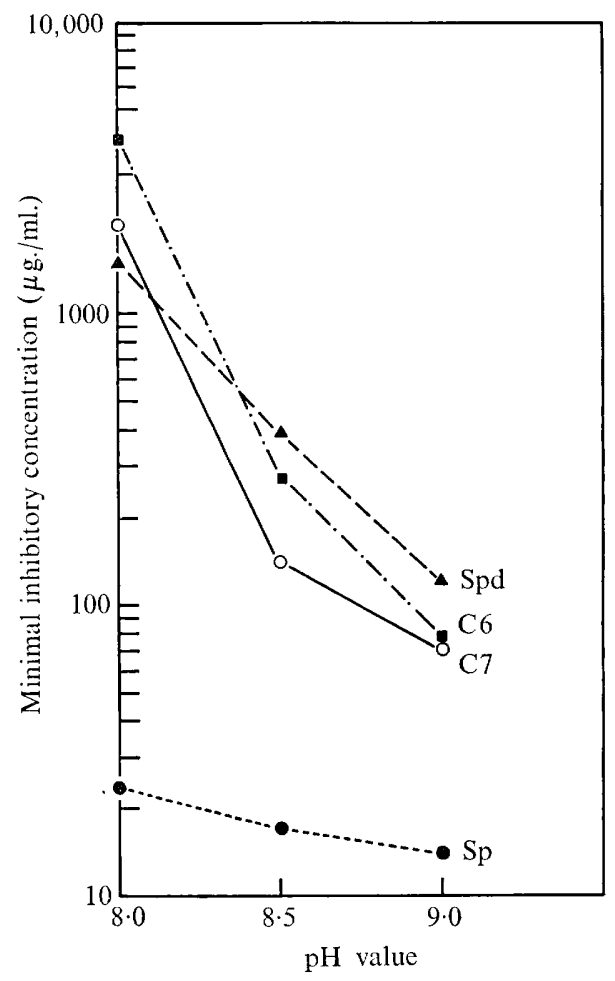

Fig. I. Effect of $\mathrm{pH}$ value on the antibacterial activity of polyamines. $\mathrm{Sp}=$ spermine; Spd $=$ spermidine $; \mathrm{C}_{6}=N$-3-aminopropylhexane, 1 ,6-diamine $; \mathrm{C}_{7}=N$-3-aminopropylheptane, I,7-diamine.

Little is known about the mechanism of antimicrobial action of polyamines. Previous studies have shown certain similarities between the action of spermine on bacteria and that of another cationic antibiotic, streptomycin. Both agents are bactericidal, have early effects on protein synthesis and RNA synthesis as well as on potassium flux (Mills \& Dubin, I966). These compounds are presumably bound to the ribosomes on identical sites (Mager et al. 1962) and both cause extensive misreading of the genetic code (Davies, Gilbert \& Gorini, 1964; Friedman \& Weinstein, 1964; Davies, Gorini \& Davis, 1965). However, the relationship between misreading, inhibition of protein synthesis and cell death has not been fully elucidated for streptomycin or spermine. 
The stimulation of RNA synthesis by polyamines (Fig. 2, 3) is in agreement with earlier findings that RNA accumulated in polyamine-inhibited cells (Pine, 1964; Goldstein, 1965). Raina \& Cohen (1966) showed that spermidine stimulated RNA synthesis in arginine-starved Escherichia coli strain $15 \mathrm{TAU}$, which requires thymine,

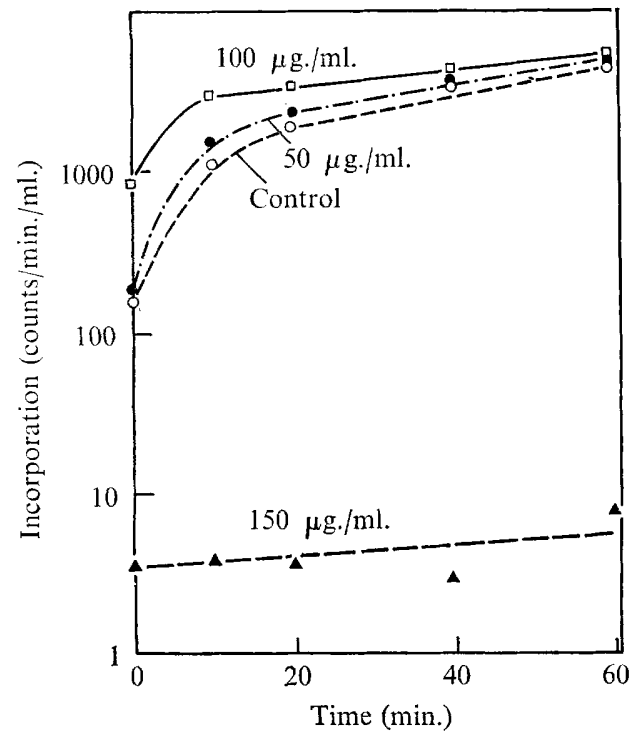

Fig. 2

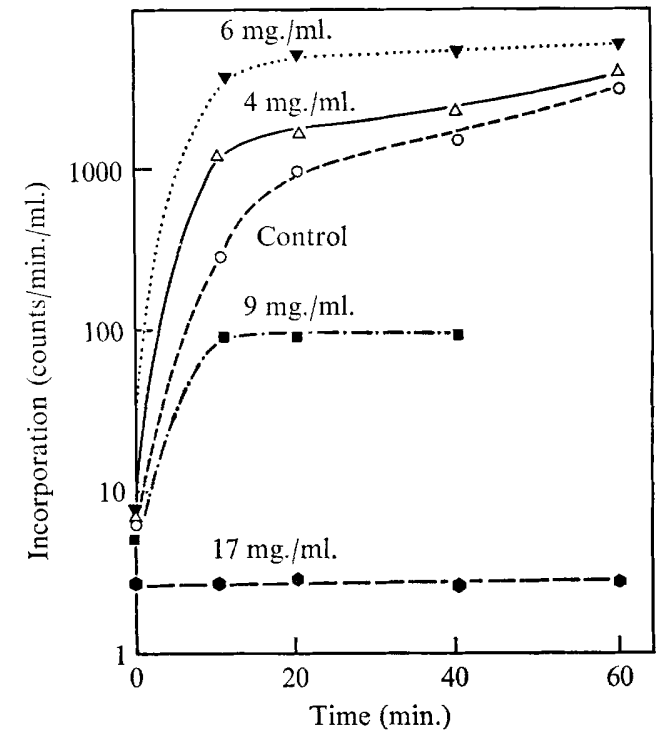

Fig. 3

Fig. 2. Effect of spermine on the incorporation of $\left[{ }^{14} \mathrm{C}\right]$ uracil into growing Escherichia coli. The organism was grown in $20 \mathrm{ml}$. quantities of nutrient broth to $5 \times 10^{8}$ organisms $/ \mathrm{ml}$. $\left[2-{ }^{14} \mathrm{C}\right]$ uracil $(\mathrm{I} \cdot 2 \mu \mathrm{Ci})$ was then added in the presence of the polyamines at the concentrations indicated. Samples $(2 \mathrm{ml}$.) were withdrawn at intervals added to equal volumes of $10 \%$ trichloroacetic acid, and the amount of incorporated isotope determined.

Fig. 3. Effect of $N$-3-aminopropylheptane, 1,7 -diamine on the incorporation of $\left[{ }^{14} \mathrm{C}\right]$ uracil into growing Escherichia coli.

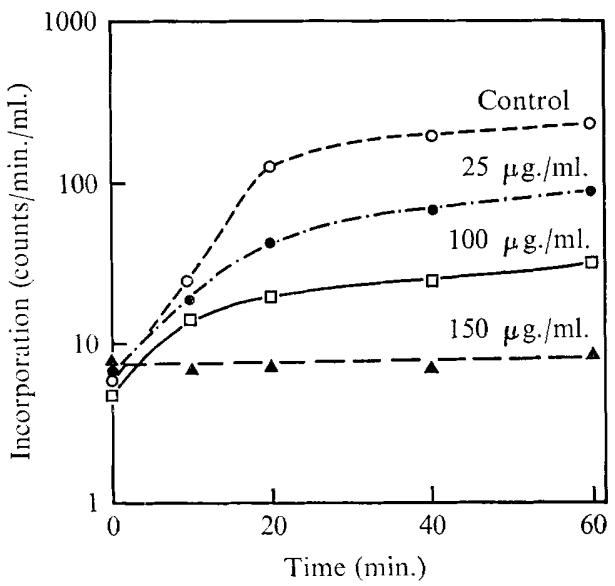

Fig. 4. Effect of spermine on the incorporation of $\left[{ }^{14} \mathrm{C}\right]$ valine into growing Escherichia coli. Experimental conditions were as in Fig. 2 , except that $\mathrm{DL}\left[\mathrm{I}-{ }^{14} \mathrm{C}\right]$ valine $(6 \cdot 8 \mu \mathrm{Ci})$ was added to each culture. 
arginine and uracil for growth. They proposed that polyamines have a causal role in the control of RNA synthesis. It has, however, been claimed (Edlin \& Broda, 1968) that the choice of $E$. coli strain I5TAU is not ideal because of the metabolic interrelationships of arginine, glutamate, putrescine and spermidine. Sparing of amino acids by polyamine in amino acid-starved bacteria has been offered as an alternative explanation for the stimulation of RNA synthesis (Ezekiel \& Brockman, 1968) Results reported in the present paper show that RNA synthesis was also stimulated in

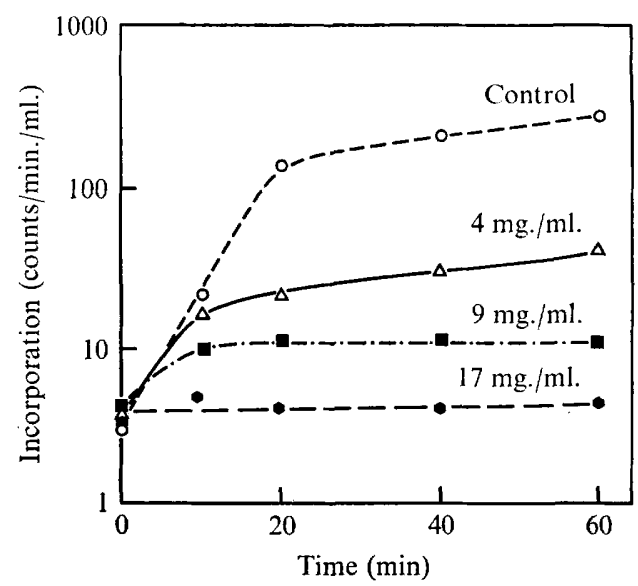

Fig. 5. Effect of $\mathrm{N}$-3-aminopropylheptane,, 7 -diamine on the incorporation of $\left[{ }^{14} \mathrm{C}\right]$ valine into growing Escherichia coli.

non-starved bacteria by the synthetic polyamine no. $\mathrm{C}_{7}$ which does not bear any known metabolic relationship with amino acids. This finding does not support a sparing of amino acids by a polyamine but would favour a direct effect of the polyamine on RNA polymerase (Fox, Gumport \& Weiss, 1965). It might also be explained by the stabilization of RNA and consequent protection against thermal denaturation (Goldstein, I966) or enzymic degradation (Bachrach \& Eilon, I969). Stimulation of protein turnover by polyamines (Ezekiel \& Brockman, 1968) might also explain the increased rate of RNA synthesis. At this stage it is difficult to distinguish between the alternative explanations and the reason for the stimulation of RNA synthesis in the presence of polyamines must await the results of further experiments.

\section{REFERENCES}

Bachrach, U. \& EILON, G. (I969). The effect of spermine and oxidized spermine on the enzymic degradation of DNA. Biochimica et Biophysica Acta 179, 494.

Caldarera, C. M., Moruzzı, M. S., Barbiroli, B. \& Moruzzi, G. (1968). Spermine and spermidine of the prostate gland of orchiectomized rats and their effect on RNA polymerase activity. Biochemical and Biophysical Research Communications 33, 266.

Davies, J., GilberT, W. \& GoRINI, L. (I964). Streptomycin, suppression and the code. Proceedings of the National Academy of Sciences of the United States of America 51, 883.

Davies, J., GorINI, L. \& Davis, B. D. (I965). Misreading of RNA codewords induced by aminoglycoside antibiotics. Molecular Pharmacology $\mathbf{1}, 93$.

Doerfler, W., Zillig, W., Fuchs, E. \& Albers, M. (1962). Untersuchungen zur Biosynthese der Proteine. V. Die Funktion von Nucleinsäuren beim Einbau von Aminosäuren in Proteine in einem zellfreien System aus Escherichia coli. Hoppe-Seyler's Zeitschrift für Physiologische Chemie 330, 96. 
Dykstra, W. G. \& Herbst, E. J. (1965). Spermidine in regenerating liver: relation to rapid synthesis of ribonucleic acid. Science, New York $149,428$.

Edlin, G. \& Broda, P. (I968). Physiology and genetics of the 'ribonucleic acid control' locus in Escherichia coli. Bacteriological Reviews 32, 208.

Ezekiel, D. H. \& Brockman, H. (1968). Effect of spermine treatment on amino acid availability in amino acid starved Escherichia coli. Journal of Molecular Biology 31, 541.

Fox, C. F., Gumport, R. I. \& WeIss, S. B. (1965). The enzymatic synthesis of ribonucleic acid. V. The interaction of ribonucleic acid polymerase with nucleic acids. Journal of Biological Chemistry 240, 2 IOI.

Fox, C. F., Robinson, W. S., Haselkorn, R. \& Weiss, S. B. (1964). Enzymatic synthesis of ribonucleic acid. III. The ribonucleic acid-primed synthesis of ribonucleic acid with Micrococcus lysodeikticus ribonucleic acid polymerase. Journal of Biological Chemistry 239, I 86.

Fox, C. F. \& WeIss, S. B. (I964). Enzymatic synthesis of ribonucleic acid. II. Properties of the deoxyribonucleic acid-primed reaction with Micrococcus lysodeikticus ribonucleic acid polymerase. Journal of Biological Chemistry 239, 175.

FraSer, D. \& MAHLER, H. R. (1958). Effect of diamines on the protoplast infecting agent derived from T 2 bacteriophage. Journal of the American Chemical Society 80, 6456.

Friedman, M. E. \& BACHRACH, U. (I966). Inhibition of protein synthesis by spermine in growing cells of Staphylococcus aureus. Journal of Bacteriology 92, 49.

Friedman, S. M. \& Weinstein, I. B. (1964). Lack of fidelity in the translation of synthetic polyribonucleotides. Proceedings of the National Academy of Sciences of the United States of America $\mathbf{5 2}, 988$.

GoldsteIN, J. (1965). The effect of spermine on the accumulation of nucleic acids and protein in mammalian cells. Experimental Cell Research 37, 494.

GoldsteIN, J. (I966). Resistance of RNA to thermal denaturation in the presence of polyamines. Biochimica et Biophysica Acta 123, 620.

Grossowicz, N., RaZiN, S. \& RozANSKy, R. (1955). Factors influencing the antibacterial action of spermine and spermidine on Staphylococcus aureus. Journal of General Microbiology r3, 436.

GuiraRd, B. M. \& SNEll, E. E. (1964). Effect of polyamine structure on growth stimulation and spermine and spermidine content of lactic acid bacteria. Journal of Bacteriology 88, 72.

Hershko, A., Amoz, S. \& MAGER, J. (I96I). Effect of polyamines and divalent metals on in vitro incorporation of amino acids into ribonucleoprotein particles. Biochemical and Biophysical Research Communications 5, 46.

Krakow, J. S. (1963). Ribonucleic acid polymerase of Azotobacter vinelandii. III. Effect of polyamines. Biochimica et Biophysica Acta 72, 566.

MAGER, J., Benedict, M. \& ARTMAn, M. (1962). A common site of action for polyamines and streptomycin. Biochimica et Biophysica Acta 62, 202.

Martin, R. G. \& Ames, B. N. (I962). The effect of polyamines and of poly U size on phenylalanine incorporation. Proceedings of the National Academy of Sciences of the United States of America 48,2171 .

Mills, J. \& Dubin, D. T. (1966). Some effects of spermine on Escherichia coli. Molecular Pharmacology 2, $3 \mathrm{II}$.

Moruzzi, G., Barbiroli, B. \& Caldarera, C. M. (1968). Polyamines and nucleic acid metabolism in chick embryo. Incorporation of labelled precursors into nucleic acids of subcellular fractions and polyribosomal patterns. Biochemical Journal ro7, 609.

O'Brien, R. L., OLENICK, J. G. \& HAHN, F. E. (I966). Reactions of quinine, chloroquinine and quinacrine with DNA and their effects on the DNA and RNA polymerase reactions. Proceedings of the National Academy of Sciences of the United States of America 55, $15 \mathrm{II}$.

OchoA, M. Jun. \& WeInsteIn, I. B. (1965). Spermine inhibition of polypeptide synthesis in a subcellular system derived from L-I 2 I 0 mouse ascites leukemia. Biochimica et Biophysica Acta 95 , 176.

Petersen, E. E., Kröger, H. \& Hagen, U. (I968). The influence of spermidine on the reaction of RNA nucleotidyltransferase. Biochimica et Biophysica Acta 16r, 325.

PINE, M. J. (1964). New inhibitors of protein synthesis in Escherichia coli. Bacteriological Proceedings p. 103.

RAINA, A. \& CohEn, S. S. (I966). Polyamines and RNA synthesis in a polyauxotrophic strain of E. coli. Proceedings of the National Academy of Sciences of the United States of America 55, 1587.

RAZIN, S. \& RozANSKy, R. (1959). Mechanism of the antibacterial action of spermine. Archives of Biochemistry and Biophysics 8r, 36.

Rozansky, R., BaChrach, U. \& Grossowicz, N. (I954). Studies on the antibacterial action of spermine. Journal of General Microbiology ro, I I.

Rozansky, R., Gurevitch, J., Brzezinsky, A. \& ECKerling, B. (1949). Inhibition of the growth of Staphylococcus aureus by human semen. Journal of Laboratory and Clinical Medicine 34, I526. 